\title{
PENENTUAN VIGOR KEKUATAN TUMBUH DAN VIGOR DAYA SIMPAN RELATIF BENIH MERBAU, AKOR DAN MINDI
}

\author{
Determination of Relative Growth Vigour and Storage Vigour of Merbau, Akor and Mindi Seeds
}

\author{
M. Zanzibar dan/and Agus Astho Pramono
}

Balai Penelitian Teknologi Perbenihan Bogor

Jl. Pakuan, Ciheulet PO. BOX 105 Bogor, 16001

Telp./Fax (0251) 8327768

Naskah masuk: 16 Juni 2008 ; Naskah diterima: 19 Februari 2009

\begin{abstract}
Seeds with high vigour are seeds with normal growth on sub optimum and above normal condition. To predict the performance of seedlings after planting and the storability of seed, it is necessary to test the seed vigour. The purpose of this research was to investigate the growth vigour and storage vigour of merbau (Intsia bijuga), akor (Acacia mangium) and mindi (Melia azedarach) seeds. The viability levels was gained through different accelerated aging treatments by means of seeds saturation using ethanol steam (90\%) and blowing heat air $\left(50^{\circ} \mathrm{C}\right)$. The experiment was arranged in completely randomized design with each treatment being replicated four times with 50 seeds. The result showed that the vigour of seeds with lower viability is more responsive to decrease. Merbau seed previously placed in under pressure condition grew as well as that on optimum condition; hence merbau seed had highest growth vigour. Merbau and akor seeds were more resistant to the effect of aging or unsuitable condition during storage period, therefore those seeds has higher storability than mindi seed.
\end{abstract}

Key words : akor, growth vigour, merbau, mindi, seeds, and storage vigour

\begin{abstract}
ABSTRAK
Benih bervigor tinggi adalah benih yang mampu berproduksi normal pada kondisi sub optimum dan di atas normal pada kondisi optimum. Untuk melihat tampilan benih setelah ditanam atau disimpan perlu dilakukan uji vigor. Penelitian ini bertujuan mengetahui vigor kekuatan tumbuh dan vigor daya simpan relatif benih merbau (Intsia bijuga), akor (Acacia auriculiformis) dan mindi (Melia azedarach). Tingkat viabilitas diperoleh dengan cara penuaan dipercepat (accelerated aging) melalui penjenuhan benih dengan uap etanol $(90 \%)$ dan hembusan udara panas $\left(50^{\circ} \mathrm{C}\right)$. Rancangan yang digunakan adalah rancangan acak lengkap dengan ulangan sebanyak 4 kali, setiap ulangan terdiri dari 50 bibit. Hasil penelitian menunjukkan bahwa pada masing-masing jenis, benih dengan tingkat viabilitas yang rendah akan lebih responsif terhadap penurunan vigor. Pada kondisi di bawah tekanan (sub optimum), benih merbau mampu tumbuh dengan baik seperti halnya pada kondisi optimum sehingga benih ini relatif memiliki vigor kekuatan tumbuh tertinggi, diikuti kemudian oleh benih akor dan mindi. Benih merbau dan akor relatif lebih tahan terhadap pengaruh penuaan atau lingkungan yang tidak menguntungkan selama masa konservasi sehingga benih ini memiliki vigor daya simpan tertinggi, dibandingkan dengan pada benih mindi.
\end{abstract}

Kata kunci : vigor, kekuatan tumbuh, daya simpan, benih merbau, akor dan mindi 


\section{PENDAHULUAN}

\section{A. Latar Belakang}

Sampai saat ini pengujian benih tanaman hutan di Indonesia masih terbatas pada uji perkecambahan yang dilakukan di laboratorium dengan kondisi yang ideal. Daya berkecambah yang dihasilkan dari pengecambahan ini tidak akan mampu menggambarkan kemampuan benih menghadapi stres lingkungan yang mungkin terjadi di lapangan dan penyimpanan, sehingga untuk keperluan operasional diperlukan uji vigor yang dapat menggambarkan potensi benih dalam kisaran kondisi lingkungan yang lebih luas. Benih yang bervigor tinggi akan mampu berproduksi normal pada kondisi sub optimum dan di atas normal; memiliki kemampuan tumbuh serempak dan cepat, dan lebih tahan untuk disimpan dalam kondisi yang tidak ideal. Vigor benih merupakan gambaran beberapa sifat dari potensi benih bukan sifat tunggal terukur sehingga tidak ada prosedur yang baku, penentuan metode hanya merupakan pilihan untuk jenis dan keperluan tertentu (AOSA, 1983). Beberapa metode uji vigor adalah uji kecepatan perkecambahan, uji daya hantar listrik, penuaan dipercepat, uji tekanan serta uji pertumbuhan semai.

Menurut Sadjad et al. (1999), untuk memperkirakan kekuatan tumbuh di lapangan, kelompok benih harus bisa disimulasi vigornya dengan menggunakan metode yang tepat. Makin dini suatu metode dapat mengindikasikan vigor benih dengan akurat akan semakin baik, baik metode tersebut untuk mengungkapkan kebenaran indikasi mutu genetik ataupun mutu fisiologis. Setiap jenis akan memiliki kriteria vigor, baik vigor kekuatan tumbuh $\left(\mathrm{V}_{\mathrm{KT}}\right)$, maupun vigor daya simpan $\left(\mathrm{V}_{\mathrm{DS}}\right)$ sendiri untuk dapat dikatakan kuat atau kurang kuat. Analisis vigor menjadi lebih sederhana apabila tolok ukur itu bersifat relatif, artinya nilai pada tolok ukur hanya untuk membandingkan suatu kelompok benih terhadap kelompok benih lainnya.

Menurut Artola et al. (2003), vigor yang rendah akan menghasilkan tegakan yang buruk, sehingga untuk kegiatan penanaman bibit yang digunakan seharusnya berasal dari benih yang bervigor tinggi. Uji vigor sangat tepat diaplikasikan pada sumber-sumber benih yang telah dikukuhkan, yaitu sumber benih yang tingkat pemuliaannya sudah tinggi, misalnya Kebun Benih (KB), Tegakan Benih Provenansi (TBP) dan Areal Pengumpulan Benih (APB). Pada sumber-sumber tersebut, besaran atau standar vigor harus mampu didefinisikan dengan benar kualitas fisiologisnya disamping kualitas genetiknya. Jaminan kualitasnya merupakan hal yang wajar diperoleh konsumen karena pengorbanan mereka untuk hal tersebut relatif besar. Benih vigor yang dicirikan oleh produksinya yang unggul harus dapat diinformasikan lebih dini bagi konsumennya, dan harus bisa disimulasi kinerjanya, seperti kinerja fisik, fisiologis dan genetik. Vigor benih yang tinggi akan menumbuhkan tanaman yang homogen (homogeneous stand) yang dalam berbagai segi akan menguntungkan pengelolanya.

\section{B. Tujuan}

Penelitian ini dilaksanakan dengan tujuan mengetahui besaran relatif vigor kekuatan tumbuh dan vigor daya simpan benih merbau, akor dan mindi.

\section{BAHAN DAN METODE}

\section{A. Tempat dan Waktu Penelitian}

Penelitian ini dilaksanakan di Laboratorium Benih - IPB dan Rumah Kaca Balai Penelitian Teknologi Perbenihan, Bogor pada Agustus hingga Desember 2005. Benih dipanen dari beberapa pohon (bulk) secara bersamaan pada bulan Juli 2005. 


\section{B. Bahan dan Alat}

Bahan dan alat yang digunakan antara lain benih merbau, akor dan mindi, etanol (90\%), mesin pengusang cepat (MPC IPB 77-1), ragum, alat pembagi contoh benih, oven, timbangan analitik, alat pembagi benih, sprayer dan bak kecambah.

\section{Metode Penelitian}

\section{Ekstraksi dan Penjemuran}

Ekstraksi benih merbau dilakukan dengan cara benih dipisahkan satu persatu dari buah, dicuci pada air mengalir lalu dijemur. Benih mindi diekstraksi dengan cara buah hasil pengunduhan yang telah masak fisiologis dilepaskan daging buahnya dengan diinjak-injak. Sisa daging buah dibersihkan dengan cara benih dicampur dengan pasir, digilas, dibilas dengan air, kemudian dijemur hingga kering. Benih akor diekstraksi dengan cara polong dimasukkan ke dalam karung kemudian dipukul-pukul dengan balok kayu, ditampi lalu dijemur. Lama penjemuran masing-masing jenis selama 4 hari.

\section{Penderaan dan Perkecambahan Benih}

a. Penelitian 1: Penentuan Vigor Kekuatan Tumbuh Relatif $\left(\mathbf{V}_{\mathbf{K T r}}\right)$. Untuk mengetahui vigor kekuatan tumbuh relatif dilakukan uji vigor, yaitu benih diuji di rumah kaca yang diasumsikan sebagai kondisi optimum dan uji tekanan (stress test) sebagai kondisi sub optimum. Uji tekanan terdiri dari metode Hiltner dan uji kejenuhan. Uji perkecambahan di rumah kaca menggunakan media campuran pasir dan tanah $(1: 1)(\mathrm{v} / \mathrm{v})$. Metode Hiltner sama dengan uji perkecambahan di rumah kaca, namun pada bagian atas media dilapisi dengan hancuran batu bata dan disusun setebal $3-4 \mathrm{~cm}$. Untuk uji kejenuhan benih juga ditempatkan pada media yang sama pada bak kecambah plastik, namun ditempatkan pada ruang gelap di laboratorium.

b. Penelitian 2: Penentuan Vigor Daya Simpan Relatif $\left(\mathbf{V}_{\mathbf{D S r}}\right)$. Benih yang telah diekstraksi dan sudah kering dilakukan penderaan (accelerated aging). Penderaan benih dilakukan dengan menggunakan alat mesin pengusang cepat (MPC IPB 77-1), uap etanol dihembuskan selama 5 menit, kemudian dengan udara panas $\left(50{ }^{\circ} \mathrm{C}\right)$ selama 10 menit $[\mathrm{x}(5+10)$ menit]. $\mathrm{x}=$ Koefisien penderaan, terdiri dari : 0, 9, 12, 15, 18 dan 21 kali (Kartika, 1984). Benih yang telah mendapat perlakuan penderaan kemudian dikecambahkan pada media campuran pasir : $\tan a h(1: 1)(\mathrm{v} / \mathrm{v})$.

\section{Rancangan Percobaan dan Analisis Data}

Rancangan percobaan yang digunakan (penelitian 1 dan 2) adalah rancangan acak lengkap (RAL). Ulangan dilakukan sebanyak 4 kali, masing-masing ulangan terdiri dari 50 butir. Perlakuan pada penelitian 1, adalah : $\mathbf{M}_{0}=$ metode perkecambahan optimum, $\mathbf{M}_{1}=$ metode Hiltner, $\mathbf{M}_{2}=$ uji kejenuhan. Perlakuan penelitian 2, adalah : $\mathrm{D}_{0}=$ kontrol, $\mathrm{D}_{1}=9(5+10)$ menit, $\mathrm{D}_{2}=12(5+10)$ menit, $\mathrm{D}_{3}=15(5+10)$ menit, $\mathrm{D}_{4}=18(5+10)$ menit, $\mathrm{D}_{5}=21(5+10)$ menit. Pengamatan dilakukan setiap hari terhadap benih yang telah berkecambah normal. Pengamatan dihentikan apabila selama 7 (tujuh) hari berturut-turut tidak ada lagi benih yang berkecambah. Data kecambah digunakan untuk menduga variabel daya berkecambah (DB), keserempakan tumbuh $\left(\mathrm{K}_{\mathrm{ST}}\right)$, kecepatan tumbuh $\left(\mathrm{K}_{\mathrm{CT}}\right)$ dan berat kering kecambah $\left(\mathrm{BK}_{\mathrm{kc}}\right)$. Analisis data menggunakan program SAS Institute Inc. (1985) melalui Uji F (Anova). Apabila uji F nyata maka dilanjutkan dengan uji berganda Duncan. 


\section{HASIL DAN PEMBAHASAN}

\section{A. Vigor Kekuatan Tumbuh Relatif $\left(V_{K T r}\right)$}

Hasil uji berganda Duncan (Tabel 1) menunjukkan bahwa metode uji berpengaruh terhadap vigor kekuatan tumbuh relatif benih merbau, akor dan mindi.

Hasil dari pengujian terhadap ketiga jenis menunjukkan bahwa benih merbau memiliki kinerja pertumbuhan yang baik di kondisi media yang bertekstur kasar. Hasil uji statistik menunjukkan bahwa tidak ada perbedaan daya kecambah antara uji rumah kaca dengan uji Hiltner. Berbeda dengan benih akor dan mindi, dibandingkan dengan uji rumah kaca, vigor benih secara nyata turun ketika diuji dengan metode Hiltner. Uji vigor ditujukan untuk menentukan potensi kecepatan dan keseragaman serta perkembangan semai pada kisaran kondisi lingkungan yang lebar. Uji tekanan bertujuan untuk menggambarkan masing-masing faktor tekanan yang mungkin terjadi pada kondisi lapangan. Benih yang dikecambahkan di bawah lapisan hancuran batu bata pada uji Hiltner akan menggambarkan kemampuan benih mengatasi tekanan fisik selama perkecambahan di lapangan (Schmidt, 2002). Hal ini akan menggambarkan apakah benih akan mampu tumbuh dengan baik pada lahan-lahan marginal (tanah bertekstur kasar) di bawah kondisi tanah yang tidak menguntungkan.

Pada umumnya kecambah akan tumbuh dengan baik jika cahaya cukup untuk kebutuhan fotosintesanya sehingga nilai vigor pada uji kejenuhan akan menggambarkan potensi benih tersebut untuk tumbuh pada kondisi gelap seperti lahan ternaung. Pada benih merbau, kondisi gelap tidak menurunkan daya kecambahnya, sedangkan pada akor dan mindi menghasilkan vigor yang paling rendah dibanding uji rumah kaca dan Hiltner, bahkan pada uji kejenuhan pada mindi tidak terjadi perkecambahan. Hal ini menunjukkan bahwa benih mindi tidak mampu untuk tumbuh pada lahan yang gelap atau ternaungi (Gambar 1). Toleransi terhadap kondisi lingkungan untuk berkecambah dan tumbuh berbeda antar jenis; jenis merbau memiliki rentang yang luas sehingga memiliki vigor kekuatan tumbuh relatif terbesar, disusul oleh akor dan mindi. Menurut Schmidt (2000), keseimbangan di antara faktor individu dari beberapa faktor yang berinteraksi pada semua jenis selama proses perkecambahan harus dicari secara hati-hati. 
Penentuan Vigor Kekuatan Tumbuh dan Vigor Daya Simpan Relatif Benih Merbau, Akor dan Mindi

M. Zanzibar dan Agus Astho Pramono 


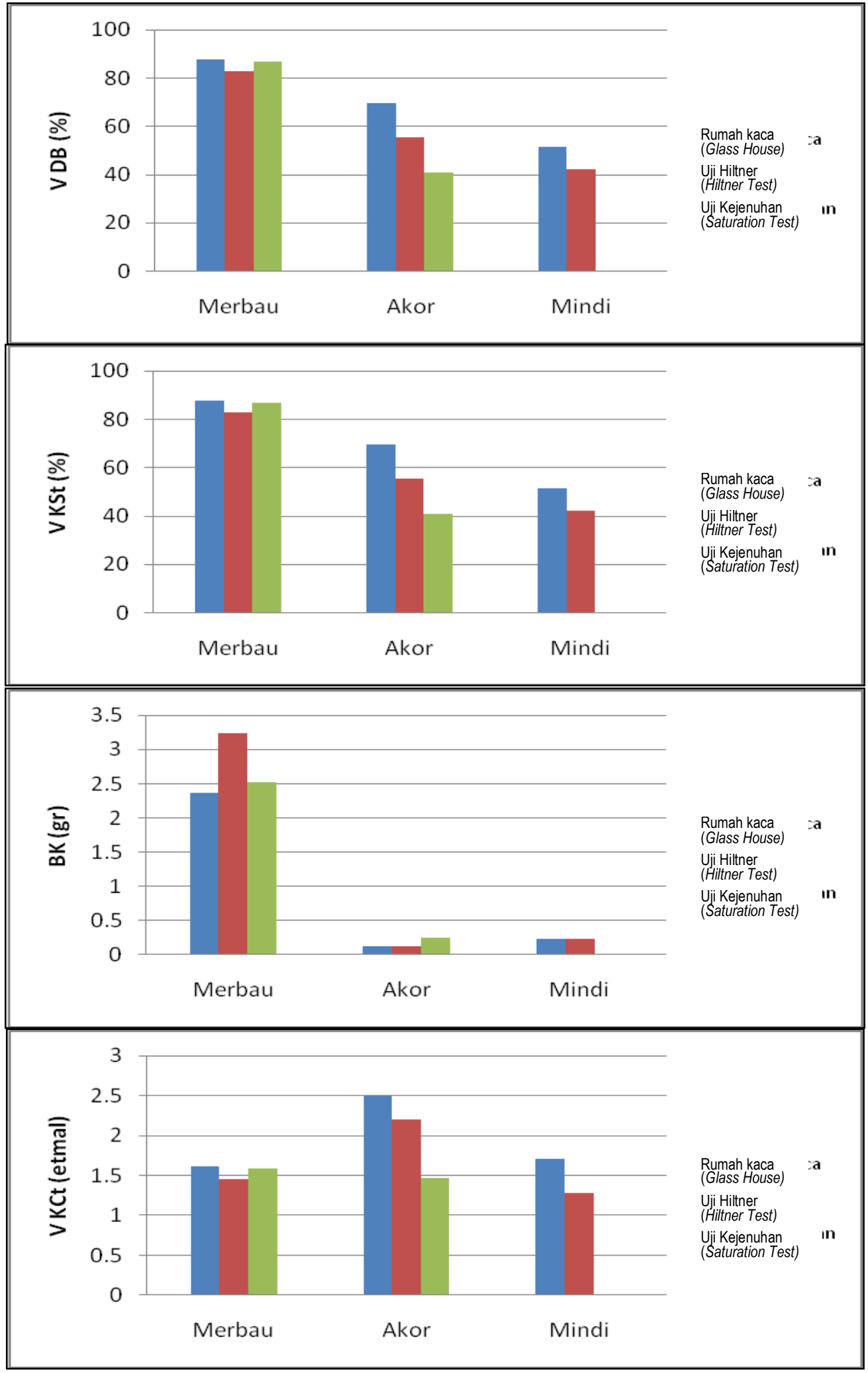

Gambar (Figure) 1. Pengaruh metode uji terhadap beberapa parameter vigor benih (Effect of test methods on different seed vigour parameters) 


\section{B. Vigor Daya Simpan Relatif $\left(\mathbf{V}_{\mathrm{DSr}}\right)$}

Daya berkecambah awal tertinggi ditunjukkan oleh benih merbau $(91,6 \%)$ kemudian disusul mindi $(60,25 \%)$ dan akor $(52,33 \%)$. Setelah proses penderaan, semua variabel vigor daya simpan cenderung menurun, kecuali pada akor yaitu pada koefisien penderaan 9 dan 15 meningkatkan vigor, kemudian taraf berikutnya cenderung menurun (Gambar 2). Dari ketiga jenis tanaman ini, benih mindi paling rentan terhadap penderaan. Pada koefisien penderaan $21 \mathrm{kali}$, daya berkecambah dan keserempakan tumbuh mindi menurun hingga 26,75\%. Uap etanol memberikan pengaruh buruk terhadap perkecambahan, namun pada benih akor hingga mencapai koefisien penderaan 12 kali $\left(D_{2}\right)$ justru mengalami peningkatan. Hal ini diduga karena perlakuan tersebut berfungsi melunakkan kulit benih yang membantu memecahkan dormansi benih akor. Gejala demikian tidak terjadi pada merbau dan mindi karena kulitnya lebih keras sehingga membutuhkan perlakuan fisik untuk memecahkan dormansinya. Berdasarkan penelitian Pramono (1998) dan Yuniarti (1997), pada benih mindi perlakuan kimiawi tidak mampu memecahkan dormansi; kulit benih harus diretakkan, sedangkan pada merbau pematahan dormansi dengan cara dikikir hingga endosperm. Dengan demikian tahap penderaan tersebut pada akor tidak mencerminkan simulasi penentuan vigor daya simpan karena penderaan justru meningkatkan semua variabel pengamatan. Penderaan yang ditujukan untuk menggambarkan perbedaan viabilitas akibat penyimpanan hendaknya memakai taraf diatas $15(5+10)$ menit. Hal ini berimplikasi pula pada penentuan viabilitas awal dan perhitungan kehilangan vigor, dimana kehilangan vigor daya simpan dimulai setelah taraf tersebut dicapai.

Perlakuan penderaan merupakan fungsi waktu; makin tinggi daya tahan benih terhadap perlakuan penderaan, diasumsikan benih tersebut memiliki daya simpan relatif yang tinggi serta dalam penyimpanannya tidak memerlukan perlakuan khusus. Berdasarkan Gambar 2, jenis merbau memiliki vigor daya simpan relatif tertinggi yang ditunjukkan oleh kecuraman grafik yang lebih datar; hingga koefisien penderaan 21 kali persentase kehilangan vigornya terendah, kemudian pada benih akor dan mindi. Meskipun ke tiga jenis ini bersifat ortodoks, namun tingkat ortodoksnya berbeda satu sama lain. Antara benih merbau dan akor kemungkinan memiliki tingkat ortodoks yang sama karena pada benih akor persentase kehilangan beberapa variabel vigornya lebih rendah. Selain itu, sangat sulit mendapatkan benih akor berviabilitas tinggi (di atas $90 \%$ ); benih bukannya tidak berkecambah tetapi perlakuan pendahuluannya belum optimum karena hingga akhir pengujian masih banyak ditemukan benih keras dan segar. Kedua benih ini meskipun tersimpan di dalam tanah selama bertahun-tahun, namun masih dapat tumbuh jika mendapatkan kondisi yang sesuai. Menurut Zanzibar (2003), tingkat ortodoks suatu benih sangat ditentukan oleh komponen penyusun kulit benih (seed coat), benih-benih yang kulitnya liat dan keras akan lebih mampu melindungi semua struktur tumbuh dari kondisi luar yang tidak menguntungkan (true orthodox). Selain itu menurut Justice dan Bass (2002), benih berkadar lemak tinggi (oily seed) cenderung tidak tahan disimpan lama, terutama apabila kandungan asam lemak tak jenuhnya pun tinggi. Proses oksidasi yang terjadi selama penyimpanan dapat memutuskan ikatan rangkap dari asam lemak tak jenuh sehingga menghasilkan radikel-radikel bebas yang dapat bereaksi dengan lipida lainnya menyebabkan rusaknya struktur membran sel. Setelah benih berlemak, kemunduran yang lebih cepat terjadi pada benih berprotein tinggi (protein seed) kemudian pada benih berkarbohidrat (starchy seed). 
Jurnal Penelitian Hutan Tanaman

Vol. 6 No.3, Juli 2009, 145-155 


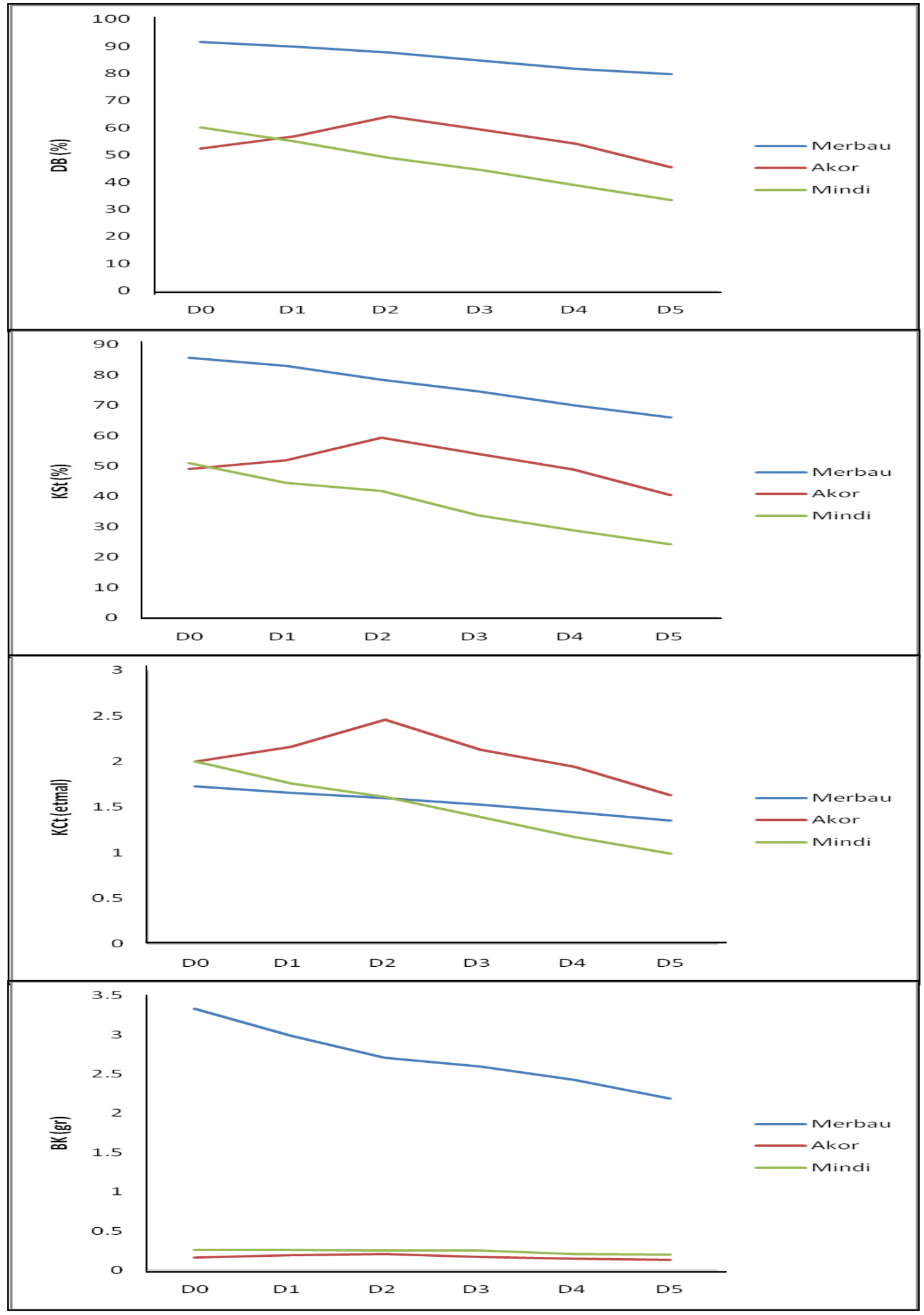

Gambar (Figure) 2. Pengaruh penderaan terhadap beberapa parameter vigor benih (Effect of accelerated aging on different seed vigour parameter) 
Pengaruh penderaan terhadap variabel perkecambahan paling tinggi terjadi pada benih mindi, namun berdasarkan berat kering bibit, ternyata pengaruh penderaan terhadap pertumbuhan kecambah paling besar terjadi pada kecambah merbau. Pada jenis mindi dan akor, benih viable memiliki kualitas fisiologis yang lebih stabil selama penyimpanan yang dicirikan dengan grafik berat kering yang datar. Berbeda dengan benih merbau, penurunan kemampuan berkecambah diikuti dengan penurunan kualitas fisiologis bibit yang dihasilkannya yang ditandai dengan rata-rata persentase kehilangan berat kering kecambah $\left(\mathrm{BK}_{\mathrm{kc}}\right)$ paling besar. Perlakuan penderaan dalam penelitian ini sangat berhubungan dengan perubahan kondisi lingkungan ekstrim, yaitu peningkatan suhu dan kelembaban nisbi, karena kedua faktor ini sangat penting pengaruhnya selama proses penuaan benih. Kelembaban nisbi berpengaruh langsung terhadap kadar air, sedangkan faktor suhu dapat meningkatkan laju reaksi biokimia benih. Menurut Robert (1983), penyimpanan benih sangat ditentukan oleh faktor internal (indigenous factor), berupa sifat-sifat genetik, kadar air dan viabilitas awal serta kandungan biokimia, sedangkan faktor luar (external factor) adalah kerusakan mekanis, serangan hama dan penyakit, kelembaban nisbi dan suhu ruang simpan serta komposisi gas dalam ruang simpan.

\section{KESIMPULAN}

Merbau, akor dan mindi memiliki toleransi terhadap kondisi lingkungan untuk tumbuh yang berbeda. Jenis merbau memiliki rentang yang luas sehingga memiliki vigor kekuatan tumbuh terbesar, kemudian diikuti oleh jenis akor dan mindi. Vigor daya simpan sangat ditentukan oleh tampilan pertumbuhan setelah benih mengalami penyimpanan (penderaan). Vigor daya simpan relatif terbesar diperoleh pada benih merbau dan akor, kemudian mindi.

\section{DAFTAR PUSTAKA}

Artola, A., de los Santos, G. Garca, CastaÃeda and G. Carrillo. 2003. A Seed Vigour Test for Birdsfoot Trefoil (Lotus corniculatus L.). Seed Science and Technology, Volume 31, Number 3. International Seed Testing Association (ISTA), pp. 753-757(5).

AOSA. 1983. Seed Vigor Testing Handbook no. 32 to the handbook on seed testing. Association of Offisial Seed Analysts. USA.

Kartika, E. 1994. Penentuan Kriteria Vigor Bibit serta Pengaruh Tingkat Devigorasi dan Densitas Benih terhadap Keberhasilan Persemaian Paraserianthes falcataria dan Acacia mangium. Tesis Fakultas Pascasarjana. IPB Bogor.

Pramono, A.A. dan Danu. 1998. Teknik Pematahan Dormansi Benih Mindi (Melia azedarach). Buletin Teknologi Perbenihan Vol. 5 No. 3. Balai Teknologi Perbenihan. Bogor.

Robert, E.H. 1983. Seed Deterorioration and Loss of Viability. In : Advances in Research and Technology of Seeds. Pudoc, Wageningen.

Sadjad, S., E. Murniati dan S. Ilyas. 1999. Parameter Pengujian Vigor Benih: dari Komparatif ke Simulatif. PT Grasindo - PT Sang Hyang Seri. Jakarta.

SAS Institute Inc. 1985. SAS User's Guide : Statistics, Version 5 edition. SAS Institute Inc., Cary. NC.

Schmidt, L. 2002. Pedoman Penanganan Benih Tanaman Hutan Tropis dan Subtropis 2000. Direktorat Jendral Rehabilitasi Lahan dan Perhutanan Sosial Departemen Kehutanan. Jakarta 
Yuniarti, N. 1997. Penentuan Cara Perlakuan Pendahuluan Benih Merbau (Intsia bijuga). Buletin Teknologi Perbenihan Vol. 4. No. 2. Balai Teknologi Perbenihan. Bogor.

Zanzibar, M. 2003. Kemunduran Viabilitas beberapa Benih Pohon Hutan akibat Pengaruh Perlakuan Pengusangan. Buletin Teknologi Perbenihan Vol. 10 No. 1. Balai Litbang Teknologi Perbenihan. Bogor. 
Tabel (Table) 1. Pengaruh metode uji terhadap vigor kekuatan tumbuh relatif $\left(\mathrm{V}_{\mathrm{KTr}}\right)$ pada benih merbau, akor dan mindi (Effect of different test methods application on the relative growth vigour and storage vigour of merbau, akor and mindi seed)

\begin{tabular}{|c|c|c|c|c|c|c|c|c|c|c|c|c|}
\hline \multirow{3}{*}{$\begin{array}{l}\text { Jenis/ } \\
\text { Species }\end{array}$} & \multirow{3}{*}{$\begin{array}{l}\text { Metode Uji/ Test } \\
\text { methods }\end{array}$} & \multicolumn{5}{|c|}{ Vigor Kekuatan Tumbuh/Growth vigour $\left(\mathrm{V}_{\mathrm{KT}}\right)$} & \multicolumn{6}{|c|}{$\begin{array}{l}\text { Kehilangan Vigor Kekuatan Tumbuh/lost growth vigour } \\
\qquad\left(\mathrm{KV}_{\mathrm{KT}}\right)\end{array}$} \\
\hline & & \multirow{2}{*}{$\mathrm{DB}(\%)$} & \multirow{2}{*}{$\mathrm{K}_{\mathrm{St}}(\%)$} & \multirow{2}{*}{$\mathrm{K}_{\mathrm{Ct}}($ etmal $)$} & \multirow{2}{*}{\multicolumn{2}{|c|}{$\mathrm{BK}_{\mathrm{kc}(\mathrm{gram})}$}} & \multirow{2}{*}{$\mathrm{DB}(\%)$} & \multirow{2}{*}{$\mathrm{K}_{\mathrm{St}}(\%)$} & \multicolumn{2}{|c|}{$\mathrm{K}_{\mathrm{Ct}}$} & \multicolumn{2}{|c|}{$\mathrm{BK}_{\mathrm{kc} \text { (gram }}$} \\
\hline & & & & & & & & & etmal & $\%$ & gram & $\%$ \\
\hline \multirow[t]{3}{*}{ Merbau } & $\mathrm{K}_{0}=$ Rumah kaca & 87.83 & $77.67 \quad \mathrm{a}$ & 1.62 & 2.37 & $\mathrm{~b}$ & 0.00 & 0.00 & 0.00 & 0.00 & 0.00 & 0.00 \\
\hline & $\mathrm{K}_{1}=\mathrm{Uji}$ Hiltner & 83.00 & $72.33 \mathrm{~b}$ & 1.45 & 3.24 & $\mathrm{a}$ & -4.83 & -5.34 & -0.17 & -10.49 & 0.87 & 36.71 \\
\hline & $\mathrm{K}_{2}=$ Uji Kejenuhan & $86.83 \mathrm{ab}$ & $78.83 \quad \mathrm{a}$ & 1.59 & 2.52 & $\mathrm{~b}$ & -1.00 & 1.16 & -0.03 & -1.85 & 0.15 & 6.33 \\
\hline \multirow[t]{3}{*}{ Akor } & $\mathrm{K}_{0}=$ Rumah kaca & 69.42 & $61.00 \quad \mathrm{a}$ & 2.49 & 0.13 & $\mathrm{~b}$ & 0.00 & 0.00 & 0.00 & 0.00 & 0.00 & 0.00 \\
\hline & $\mathrm{K}_{1}=$ Uji Hiltner & 55.50 & $52.58 \quad \mathrm{~b}$ & 2.20 & 0.13 & $\mathrm{~b}$ & -13.92 & -8.42 & -0.29 & -11.65 & 0.00 & 0.00 \\
\hline & $\mathrm{K}_{2}=$ Uji Kejenuhan & 41.08 & $38.25 \mathrm{c}$ & 1.47 & 0.25 & $\mathrm{a}$ & -28.34 & -22.75 & -1.02 & -40.96 & 0.12 & 92.31 \\
\hline \multirow[t]{3}{*}{ Mindi } & $\mathrm{K}_{0}=$ Rumah kaca & 51.67 & $43.67 \quad \mathrm{a}$ & 1.70 & 0.23 & $\mathrm{a}$ & 0.00 & 0.00 & 0.00 & 0.00 & 0.00 & 0.00 \\
\hline & $\mathrm{K}_{1}=\mathrm{Uji}$ Hiltner & 42.08 & $31.00 \mathrm{~b}$ & 1.28 & 0.24 & $\mathrm{a}$ & -9.59 & -12.67 & -0.42 & -24.71 & 0.01 & 4.35 \\
\hline & $\mathrm{K}_{2}=$ Uji Kejenuhan & 0.00 & 0.00 & 0.00 & 0.00 & & -51.67 & -43.67 & -1.70 & -100 & -0.23 & -100 \\
\hline
\end{tabular}

Keterangan (Note): Nilai-nilai pada kolom yang sama yang diikuti oleh huruf yang sama pada masing-masing jenis berbeda pada taraf kepercayaan $99 \%$ (The value in the same collumns followed by the same letters for each species are not significantly different at DMRT 0.01) 
Tabel (Table) 2. Pengaruh penderaan terhadap vigor daya simpan relatif $\left(\mathrm{V}_{\mathrm{DSr}}\right)$ pada benih merbau, akor dan mindi (The effect of accelerated aging on relative storage vigour of merbau, akor and mindi seeds)

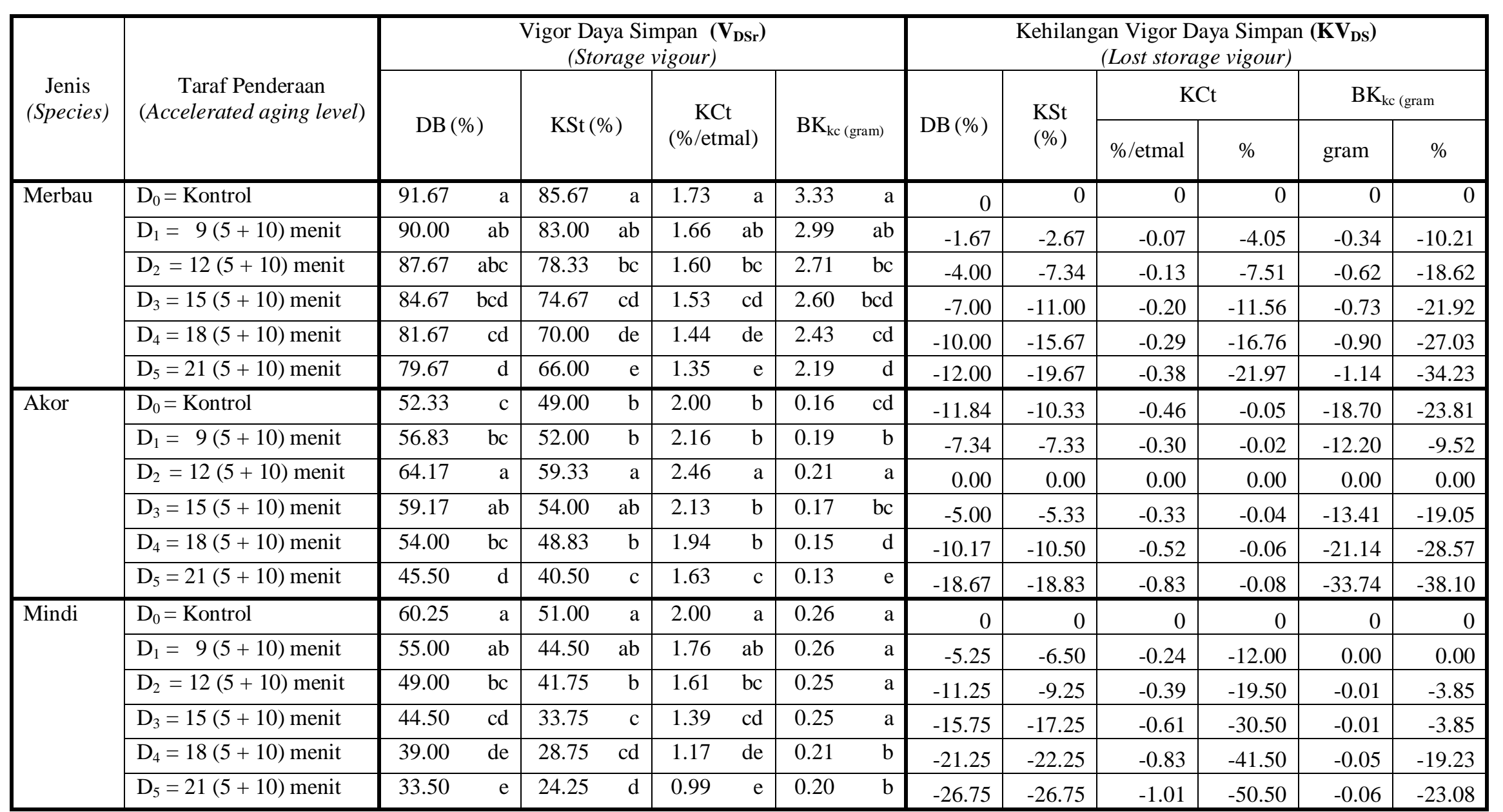

Keterangan (Note): Nilai-nilai pada kolom yang sama yang diikuti oleh huruf yang sama pada masing-masing jenis berbeda pada taraf kepercayaan $99 \%$ (The value in the same column followed by the same letters for each species are not significantly different at DMRT 0.01) 